\title{
Anaerobic 3-methylhopanoid production by an acidophilic photosynthetic purple bacterium
}

\author{
Marisa H. Mayer ${ }^{1}$ (D) Mary N. Parenteau ${ }^{2} \cdot$ Megan L. Kempher $^{3} \cdot$ Michael T. Madigan $^{4} \cdot$ Linda L. Jahnke $^{2}$. \\ Paula V. Welander ${ }^{1}$
}

Received: 2 April 2021 / Revised: 27 August 2021 / Accepted: 30 August 2021 / Published online: 16 September 2021

(c) The Author(s) 2021

\begin{abstract}
Bacterial lipids are well-preserved in ancient rocks and certain ones have been used as indicators of specific bacterial metabolisms or environmental conditions existing at the time of rock deposition. Here we show that an anaerobic bacterium produces 3-methylhopanoids, pentacyclic lipids previously detected only in aerobic bacteria and widely used as biomarkers for methane-oxidizing bacteria. Both Rhodopila globiformis, a phototrophic purple nonsulfur bacterium isolated from an acidic warm spring in Yellowstone, and a newly isolated Rhodopila species from a geochemically similar spring in Lassen Volcanic National Park (USA), synthesized 3-methylhopanoids and a suite of related hopanoids and contained the genes encoding the necessary biosynthetic enzymes. Our results show that 3-methylhopanoids can be produced under anoxic conditions and challenges the use of 3-methylhopanoids as biomarkers of oxic conditions in ancient rocks and as prima facie evidence that methanotrophic bacteria were active when the rocks were deposited.
\end{abstract}

Keywords Anoxygenic phototrophs $\cdot$ Rhodopila globiformis $\cdot$ Hopanoids $\cdot$ Warm thermal springs

\section{Introduction}

Hopanoids are triterpenoid lipids that support membrane integrity and permeability in certain bacteria (Ricci et al. 2017). Hopanoids are also quite recalcitrant biomolecules; their hopane derivatives can be preserved in sedimentary rocks for billions of years, and because of this, have been exploited as biomarkers of past environmental conditions or particular microbial activities (Brocks et al. 2005). While hopanoids are produced by metabolically diverse bacteria, hopanoids methylated in the A-ring are more restricted in

Communicated by Erko Stackebrandt

Mary N. Parenteau

mary.n.parenteau@nasa.gov

1 Department of Earth System Science, Stanford University, Stanford, CA 94305, USA

2 Exobiology Branch, NASA Ames Research Center, Moffett Field, CA 94035, USA

3 Department of Microbiology and Plant Biology, University of Oklahoma, Norman, OK 73019, USA

4 Department of Microbiology, Southern Illinois University, Carbondale, IL 62901, USA their distribution and linked to particular bacterial taxa or aerobic metabolisms. For example, hopanoids methylated at the C-2 position (2-methylhopanoids) have traditionally been linked to cyanobacteria (Summons et al. 1999) whereas hopanoids methylated at the C-3 position (3-methylhopanoids) have been associated with strictly aerobic methaneoxidizing and acetic acid-oxidizing bacteria (Zundel and Rohmer 1985).

In 2007, 2-methylhopanoid production was reported in photosynthetically grown cultures of the purple nonsulfur (PNS) bacterium Rhodopseudomonas (Rps.) palustris (Rashby et al. 2007), a widely distributed species that inhabits freshwater lakes and fertile soils (Harwood and Gibson 1988). PNS bacteria are a phylogenetically diverse group of anoxygenic phototrophs that preceded cyanobacteria on Earth by at least 500 million years and whose photosynthetic metabolism is strictly anaerobic (Hohmann-Marriott and Blankenship 2011). These Alpha- and Betaproteobacteria inhabit various aquatic environments, including lakes, wastewaters, hot springs, and marine and hypersaline waters and typically can conserve energy from both photosynthesis (anoxic/light) or respiration (oxic/dark) (Madigan and Jung 2009). Subsequent metagenomic analyses showed that $h p n P$, the gene encoding the enzyme that methylates hopanoids at 
the C-2 position, was present in microbes from samples of a variety of microbial ecosystems, suggesting that 2-methylhopanoid production is widespread in nature (Ricci et al. 2015). Collectively, these discoveries demonstrated the danger in unambiguously linking the presence of 2-methylhopanes (the breakdown product of 2-methylhopanoids) in ancient sediments to cyanobacteria or to oxic conditions in general.

In contrast to 2-methylhopanoids, evidence to date has shown that hopanoids methylated at the C-3 position (3-methylhopanoids) (Summons et al. 1999; Rashby et al. 2007) are synthesized only by bacteria that perform $\mathrm{O}_{2}$-dependent metabolisms, with the most prominent producers being aerobic methane-oxidizing bacteria (methanotrophs) and acetic acid bacteria (Zundel and Rohmer 1985). The hpnR gene that encodes the C-3 hopanoid methylase has also been detected in a diverse array of aerobic bacteria further confirming the link to $\mathrm{O}_{2}$-dependent metabolisms (Welander and Summons 2012). Moreover, lipid analyses of microbial mat samples from hypersaline environments detected 3-methylhopanoids in various bacteria, including species of PNS bacteria (Jahnke et al. 2014). In our studies of hot spring microbial mats, we detected 3-methylhopanoids in mat samples collected from a sulfidic and acidic $(\mathrm{pH}$ 3-4) spring in Lassen Volcanic National Park (California, USA) that was fed by a continuous discharge of warm volcanic water containing $\mathrm{CO}_{2}, \mathrm{H}_{2}$, and $\mathrm{H}_{2} \mathrm{~S}$ (Fig. 1a, b). The mat lacked cyanobacteria but contained a purple-red layer underneath a green-pigmented algal layer. Knowing that 3-methylhopanoids have not been reported from algae, we pursued the Lassen purple bacterium as the possible source of these lipids and, using standard enrichment and isolation techniques, obtained a pure culture of this phototroph we have designated Rhodopila strain LVNP, most closely related to another acid spring dwelling PNS, Rhodopila globiformis (Fig. 1c). Here we show that pure cultures of this organism and its phylogenetic close relative produce a suite of 3-methylhopanoids when grown under strictly anoxic conditions - the first report of the production of these hopanoid lipids in an anaerobically-grown bacterium - and that their genomes encode the requisite enzymes for methylating these lipids in the $\mathrm{C}-3$ position.

\section{Materials and methods}

\section{Organisms, isolation, and growth conditions}

Lipid analyses and genomic studies were performed on axenic cultures of four purple nonsulfur bacteria: Rhodopila strain LVNP, Rhodopila globiformis 7950 isolated from Yellowstone National Park (YNP), Rhodoblastus acidophilus 7050, and Rhodopseudomonas palustris DSM127 (the latter three species from the collection of MTM) (Table 1). Rhodopila strain LVNP was isolated from a microbial mat that formed in an acidic ( $\mathrm{pH} 3.9)$, sulfidic spring in Lassen Volcanic National Park (near 40 27' 09.5' N 121 '32' 13.3" W, Northern California, U.S.A.). The mat had an upper algal layer and a lower purple-red layer (Fig. 1). A sample of the purple layer was incubated in liquid medium (Pfennig 1974) under anaerobic photosynthetic conditions at $25^{\circ} \mathrm{C}$, and an axenic culture was eventually obtained from successive transfers of isolated colonies grown on plates of the same medium incubated in a Mitsubishi AnaeroPack 2.5L Rectangular Jar (Thermo Scientific Cat No. R685025). Anoxic conditions in liquid culture media were achieved by first vigorously sparging under filtered argon $(0.2 \mu \mathrm{m}$ filter $)$ for $5 \mathrm{~min}$, and then reducing the media with a sodium sulfide solution to scavenge any remaining oxygen. The $100 \mathrm{mM}$ sodium sulfide stock solution was anoxically prepared, neutralized to $\mathrm{pH} 7.5$, aseptically filtered, and added to the sparged media to a final concentration of $0.14 \mathrm{mM}$ prior to inoculation. To further ensure anoxia during incubation, inoculated anoxic media were transferred to tissue culture flasks and incubated in the AnaeroPack Jar under incandescent light for anaerobic photosynthetic growth. Anoxic conditions are important to maintain carefully for photosynthetic growth of Rpi. globiformis and other classical anoxygenic phototrophs because oxygen represses pigment synthesis in these organisms (Yildiz et al. 1991). Our cultures were also grown aerobically under darkness to compare the lipid composition of aerobic and anaerobic growth (Table 1). Our dark, aerobic cultures were grown in the same liquid media and tissue culture flasks as our photosynthetic, anaerobic cultures; however no sparging, no addition of sulfide, and no incubation in the AnaeroPack Jar were applied to the media. The Rpi. globiformis 7950 YNP (DSM161), Rbl. acidophilus 7050, and Rps. palustris DSM127 were grown under similar anaerobic photosynthetic conditions at $25^{\circ} \mathrm{C}$.

\section{Lipid and genomic analyses}

For analysis of lipids, cells were harvested from cultures by centrifugation at $4500 \times g$ for $10 \mathrm{~min}$ at $4{ }^{\circ} \mathrm{C}$, frozen at $-80{ }^{\circ} \mathrm{C}$, then freeze-dried for storage prior to analysis. The freeze-dried cells were resuspended in water and extracted using a modified Bligh-Dyer (B-D) protocol as previously described (Jahnke et al. 1992). Briefly, the initial B-D solvent phase of cell/water-methanol-chloroform (4:10:5) was sonicated for one hour, then physically agitated by vigorous shaking. The solvent phase (lipid/water-methanol-chloroform) was removed after centrifuging to pellet cellular residue and the extraction procedure repeated. The solvent phase of each extraction was separated by addition of chloroform and water to a final ratio of 9:10:10, the resulting 

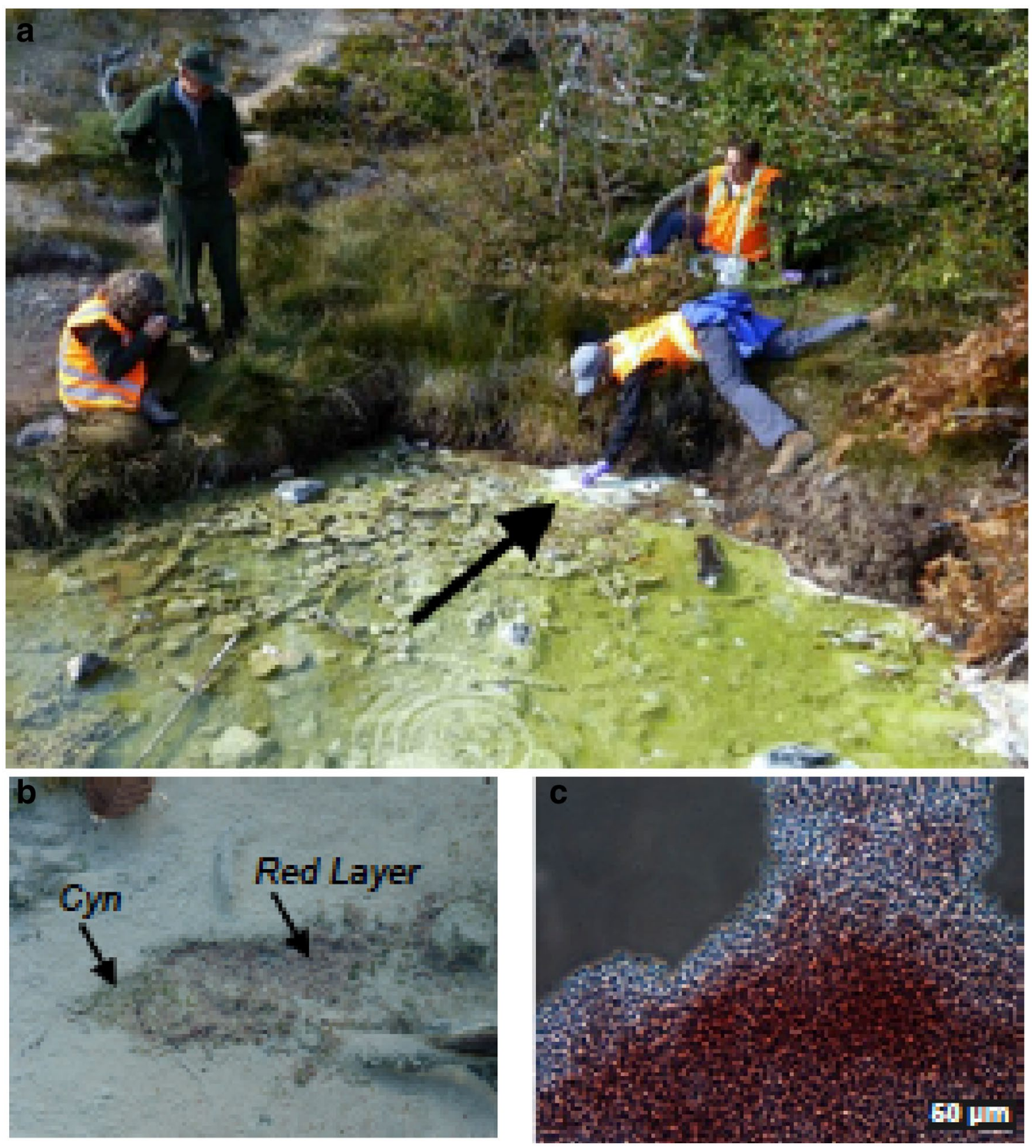

Fig. 1 a Acidic (pH 3.9) and sulfidic warm spring in Lassen Volcanic National Park. b Sampling area designated by black arrow in a. The microbial mat contains the red alga Cyanidium (Cyn) overlying a red

bottom chloroform layers containing the lipid was removed and pooled to generate a total lipid extract (TLE).

A portion of the TLE was analyzed for intact polar lipid fatty acids (IPFA) by alkaline methanolysis (Jahnke et al. 2001). Another portion of the TLE was treated with the oxidation-reduction procedure as described by Rohmer et al. (1984), which removes the polyol side chain from the hopanoid molecule. The resulting extended hopanol products and free hopanoids (diploptene, diplopterol) were derivatized with acetic anhydride (Rohmer et al. 1984) layer from which Rhodopila strain LVNP was isolated; the white area is elemental sulfur. $\mathbf{c}$ Phase-contrast photomicrograph of a dense suspension of cells of strain LVNP

and were analyzed using an Agilent 5977A Gas Chromatograph-Mass Selective Detector (GC-MSD) equipped with a $60 \mathrm{~m}$ DB5ms fused silica column. For quantitation, cholestanol-acetate and dibehenoyl-phosphatidylcholine were used as a hopanol and IPFA internal standards, respectively. The quantified hopanoids and other pentacyclic triterpenoids were normalized by grams of lyophilized biomass extracted to allow comparison between cultures (Table 1). The recovered hopanol, 2-methyl- and 3-methylhopanol products were identified based on their mass 
Table 1 Hopanoid and other pentacyclic triterpenoid composition of pure cultures analyzed in this study via GC-MSD

\begin{tabular}{|c|c|c|c|c|c|c|c|}
\hline Organism & Growth conditions & $\begin{array}{l}\text { Diplop- } \\
\text { tene } \\
(\mu \mathrm{g} / \mathrm{g})\end{array}$ & $\begin{array}{l}\text { Diplop- } \\
\text { terol } \\
(\mu \mathrm{g} / \mathrm{g})\end{array}$ & $\begin{array}{l}\text { Tetrahy- } \\
\text { menol } \\
(\mu \mathrm{g} / \mathrm{g})\end{array}$ & $\begin{array}{l}\text { Bacterioho- } \\
\text { pane-polyols } \\
(\mu \mathrm{g} / \mathrm{g})\end{array}$ & $\begin{array}{l}\text { 3-methyl- } \\
\text { hopanoids } \\
(\mu \mathrm{g} / \mathrm{g})\end{array}$ & $\begin{array}{l}\text { 3-methylho- } \\
\text { panoid/ Total } \\
\text { hopanoids }\end{array}$ \\
\hline Rhodopila strain LVNP & $\begin{array}{l}\text { Anaerobic photohetero- } \\
\text { trophic growth in light }\end{array}$ & 3.8 & nd & nd & 26 & 3.7 & 0.14 \\
\hline Rhodopila strain LVNP & Aerobic growth in dark & 37 & nd & nd & 40 & 1.7 & 0.04 \\
\hline $\begin{array}{l}\text { Rhodopila globiformis } 7950 \\
\text { YNP }\end{array}$ & $\begin{array}{l}\text { Anaerobic photohetero- } \\
\text { trophic growth in light }\end{array}$ & 43 & nd & nd & 123 & 4.7 & 0.04 \\
\hline $\begin{array}{l}\text { Rhodoblastus acidophilus } \\
7050^{\mathrm{a}}\end{array}$ & $\begin{array}{l}\text { Anaerobic photohetero- } \\
\text { trophic growth in light }\end{array}$ & 270 & nd & nd & 122 & nd & nd \\
\hline $\begin{array}{l}\text { Rhodopseudomonas palus- } \\
\text { tris DSM } 127^{\mathrm{b}}\end{array}$ & $\begin{array}{l}\text { Anaerobic photohetero- } \\
\text { trophic growth in light }\end{array}$ & 101 & 37 & 253 & 140 & nd & nd \\
\hline
\end{tabular}

LVNP Lassen Volcanic National Park, YNP Yellowstone National Park, 3-methylhopanoid 3-methylbacteriohopanepolyol, nd not detected

${ }^{a}$ Rhodoblastus acidophilus 7050 is the same culture as analyzed by Rohmer et al. (1984) for hopanoids

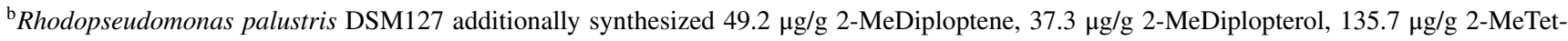
rahymanol, $4.2 \mu \mathrm{g} / \mathrm{g} 2$-methylhopanoid, and displayed a ratio of 0.03 2-methylhopanoid/Total hopanoid

spectra and retention times as described in Summons and Jahnke (1990) and references therein, and elution patterns reported in Sessions et al. (2013). Briefly, the mass fragment 191 is diagnostic of unmethylated hopanoids, while the 205 fragment is diagnostic of their methylated equivalent. Also, 3-methylhopanoids elute after their unmethylated equivalents, whereas, 2-methylhopanoids elute before.

For liquid chromatography-mass spectrometry (LC-MS) of intact hopanoid molecules to characterize the extended hopanoids present, a portion of the TLE was analyzed as previously described (Talbot et al. 2003, 2007) using an Agilent 1200 series HPLC and an Agilent 6520 quadrupole time-of-flight mass spectrometer equipped with a Poroshell 120 EC-C18 column (Agilent Technologies) following the protocol of Matys et al. (2019). Hopanoids were identified by retention time and MS2 fragment spectra, and accurate molecular mass and abundances were corrected using authentic standards of diplopterol and BHT kindly supplied by the Summons Lab, Massachusetts Institute of Technology. Since not all compounds shown in Table 2 have authentic standards required for quantification via LC-MS, we do not report relative abundances but simply the presence or absence of a specific compound based on identification of its retention time, MS2 fragment spectra, and accurate molecular mass.

Genomic DNA from Rhodopila LVNP was isolated using the Genomic Tip 500/G Kit (Qiagen Cat No. 10262) and sequenced by PacBio whole genome sequencing in collaboration with the 2016 Microbial Diversity Course (Marine Biological Laboratory, Woods Hole, U.S.A.). The genome was then assembled and annotated by the Joint Genome Institute annotation pipeline (Huntemann et al. 2015). Autoannotation of all hopanoid biosynthesis genes was confirmed by manual sequence alignment and visual inspection to confirm the auto-annotation results. This genome is available publicly in the Joint Genome Institute's IMG Database under the Genome ID Number 2684622831.

The 16S rRNA gene of Rhodopila sp. LVNP was amplified using primers $8 \mathrm{~F}$ and $1492 \mathrm{R}$ (Turner et al. 1999) and sequenced in this study; all other sequences were obtained from Genbank and analyzed using BLASTN (Altschul et al. 1997). Nearly complete ( 1400 nucleotides) 16 S rRNA gene sequences were aligned using CLUSTAL (Sievers et al. 2011) and a maximum likelihood phylogenetic tree was generated using PhyML (version 3.2) with the GTR substitution model and bootstrap analysis of 1000 replicates (Guindon et al. 2010). HpnR sequences were identified in the Joint Genome Institute IMG microbial database by protein-protein BLAST (Altschul et al. 1990; Chen et al. 2019), aligned using MUSCLE (Edgar 2004), and maximum likelihood trees built using PhyML (Guindon et al. 2010; Lefort et al. 2017). Our query sequence was the HpnR from Methylococcus capsulatus BATH (Locus Name MCA0738; $E$ value 1e-50). The tree was then exported and annotated in iTOL (Letunic and Bork 2019).

\section{Results}

\section{Characterization of a new Rhodopila isolate}

Although Rhodopila (originally Rhodopseudomonas) globiformis has been known since 1974, a second isolate of this organism has until now not been reported. In field studies, a spring was discovered in Lassen Volcanic National Park (California, USA) that was geochemically similar to the warm acidic spring that yielded Rpi. globiformis (Pfennig 
Table 2 LC-MS determination of extended hopanoids produced in Rhodopila sp. LVNP (structures referenced from Zhu et al. 2011)

Extended Hopanoid $(\mathrm{m} / \mathrm{z})$

Structure

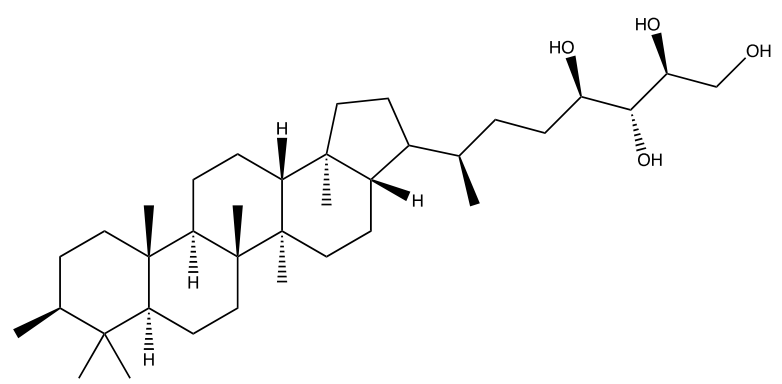

Aminotriol

714

Bacteriohopanetetrol

655

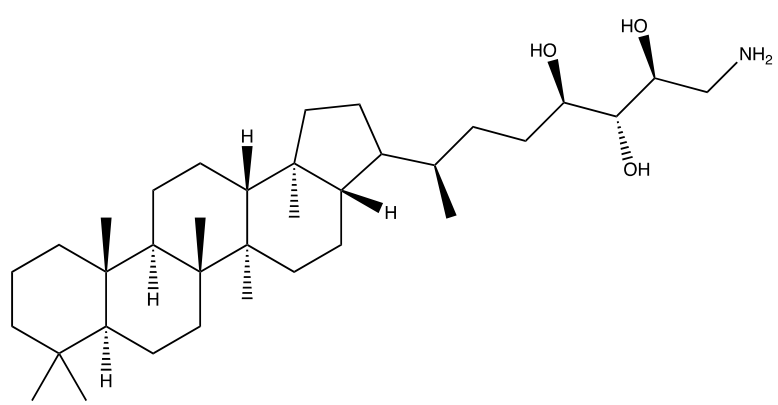

\section{Bacteriohopanetetrol}

Bacteriohopanetetrol cyclitol ether

Bacteriohopanepentol cyclitol ether

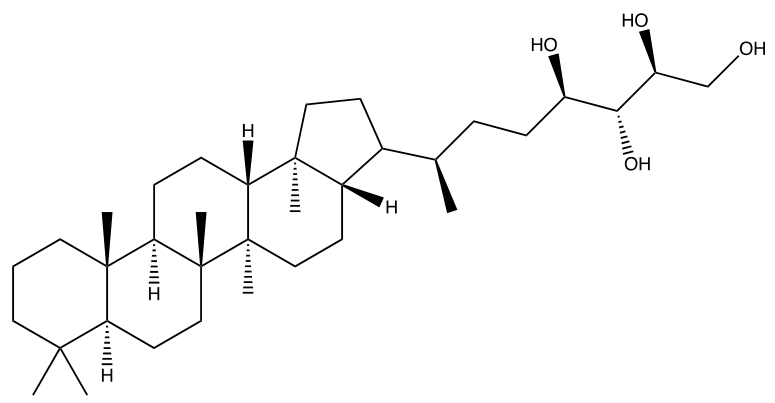

1002

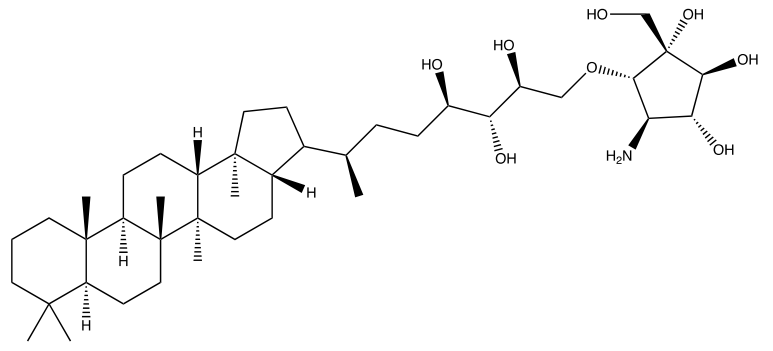

1060

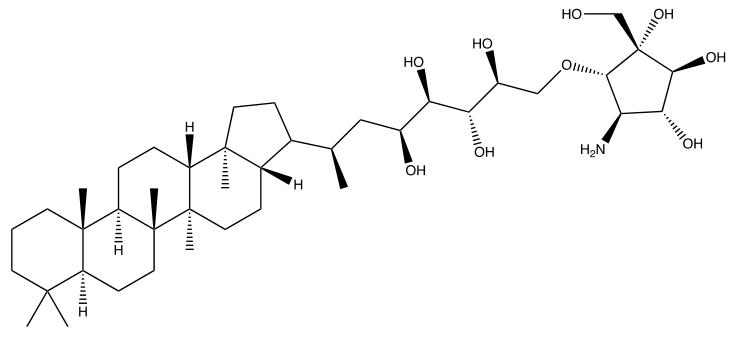

1974) and contained a microbial mat of the strongly acidophilic red alga Cyanidium overlying a purple-red layer. Cells from the latter appeared similar to those of Rps. globiformis (large weakly motile cocci) and so cultures were pursued and eventually obtained. Considering its habitat, pigments, physiology, and cell morphology, the Lassen purple bacterium was thought to be a new strain of Rhodopila globiformis and thus was tentatively designated Rhodopila strain LVNP. 


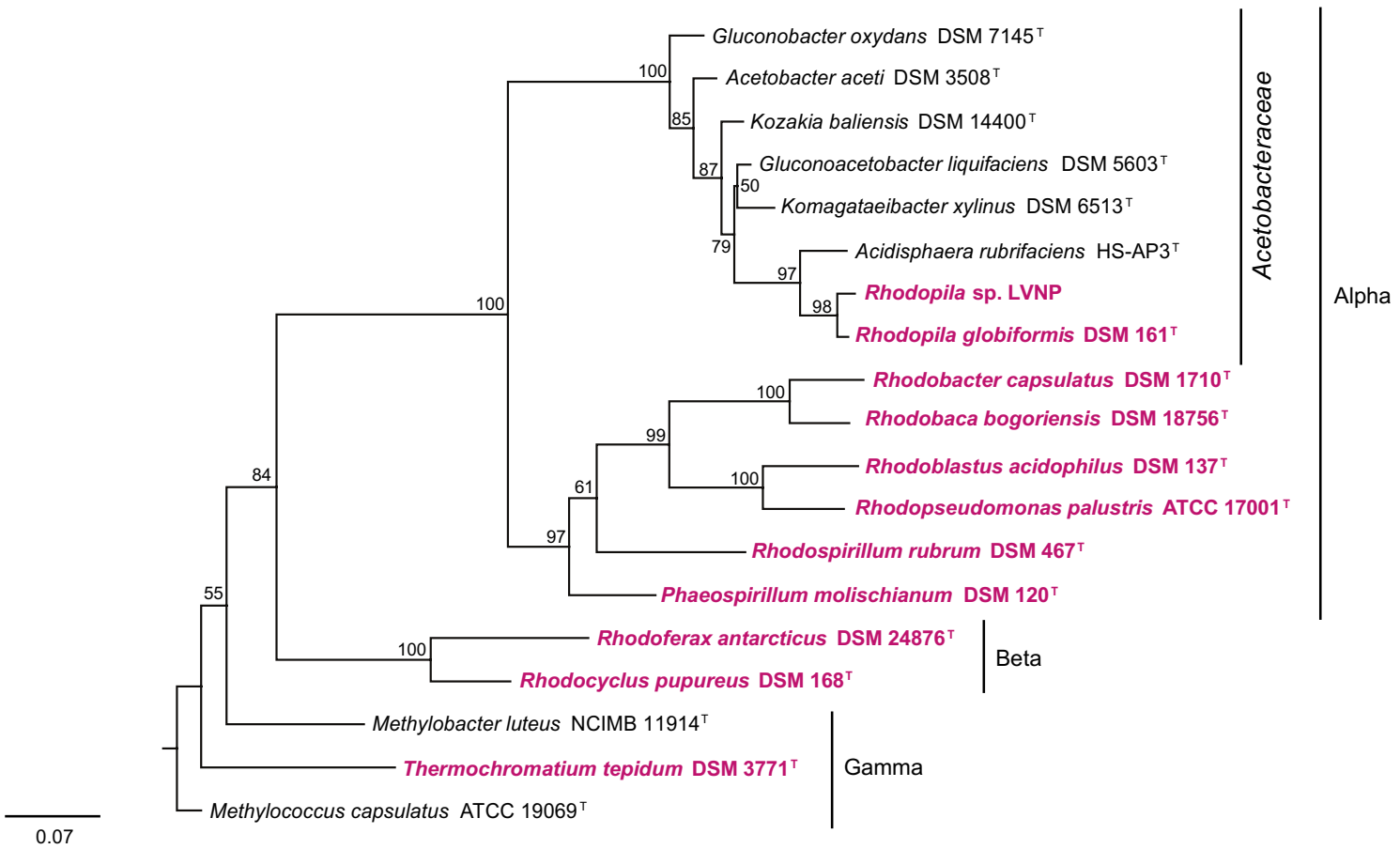

Fig. 2 Phylogenetic tree of 16S rRNA genes from some phototrophic purple bacteria and 3-methylhopanoid-producing bacteria. Taxa shown in red are anoxygenic phototrophs and all are PNS bacteria except for the purple sulfur bacterium Thermochromatium tepidum. All Acetobacteraceae shown and the two methanotrophic bacteria

A 16S rRNA gene phylogenetic tree (Fig. 2) revealed that the Lassen and Yellowstone Rhodopila isolates were closely related yet phylogenetically distinct. The percent 16S rRNA gene identity between strain Rhodopila sp. LVNP and Rhodopila globiformis 7950 YNP (DSM161) was 97\%. Moreover, the genome of the Lassen isolate $(8.1 \mathrm{Mb})$ was significantly larger than that of Rpi. globiformis $(7.2 \mathrm{Mb}$, Imhoff et al. 2018) and the average nucleotide identity between the two genomes was only $93.1 \%$. Thus, the two strains may be separate Rhodopila species rather than strains of the same species. Rhodopila is the most acidophilic PNS bacterium (Imhoff and Madigan 2021) and produces unique purple-red carotenoids (Fig. 1c) (Schmidt and Liaaen-Jensen 1973) closely related to okenone, a carotenoid detected in 1.6 Gyr-old rocks from Northern Australia (Brocks et al. 2005; Brocks and Schaeffer 2008). Rhodopila is also phylogenetically distinct from other PNS bacteria and is the only anaerobic and acidophilic phototroph that groups with the Acetobacteraceae, a bacterial family that includes acetic acid-producing bacteria and other aerobic and acidophilic bacteria (Kersters et al. 2006); this can be seen clearly in Fig. 2.
(Methylobacter luteus and Methylococcus capsulatus) are known producers of 3-methylhopanoids. The labels "Alpha," "Beta" and "Gamma" refer to classes of the phylum Proteobacteria, and numbers at the nodes are bootstrap percentages based on 1000 replications

\section{Hopanoid analyses}

Lipid analyses of pure cultures of strain LVNP and the type strain of Rpi. globiformis 7950 YNP (DSM 161) grown anaerobically photosynthetically (Pfennig 1974) revealed 3-methylhopanoid production by both strains (Table 1). GC-MSD analyses (Zundel and Rohmer 1985; Summons and Jahnke 1990) confirmed that the hopanoids were indeed 3-methylhopanoids (Fig. 3a) and not 2-methylhopanoids (Fig. 3b). Strain LVNP grown anaerobically photosynthetically at $\mathrm{pH} 5$ synthesized $0.9 \mu \mathrm{g}$ hopanoid/mg total fatty acid, $0.03 \mu \mathrm{g} 3$-methylhopanoid/mg total fatty acid, and 3 -methylhopanoids were $14 \%$ of the total hopanoid content (3-methylhopanoid/total hopanoid ratio of 0.14 ). When strain LVNP was grown aerobically in the dark, 3-methylhopanoid production decreased (3-methylhopanoid/total hopanoid ratio of 0.04). The type strain Rpi. globiformis 7950 YNP also synthesized less 3-methylhopanoid than the LVNP strain (3-methylhopanoid/total hopanoid ratio of 0.04). Both of these strains synthesized diploptene, but not diplopterol (Table 1). By contrast, phototrophic cultures of the mildly acidophilic PNS bacterium Rbl. acidophilus 7050 and the neutrophilic Rps. palustris (DSM127) (Fig. 3) did not produce 3-methylhopanoids. Rohmer et al. (1984) also did not detect 3-methylhopanoids in Rbl. acidophilus 7050. Rps. 
Fig. 3 a Gas chromatographicmass spectrometric analyses of 3-methylhopanoids. The compounds, extracted from cultures of Rhodopila strain LVNP grown photosynthetically at $\mathrm{pH}$ 5 , are separated and analyzed as their acetate derivatives. The mass fragment 191 is diagnostic of unmethylated hopanoids (blue chromatogram) while the 205 fragment is diagnostic of their methylated equivalent (red chromatogram). The 3-methylhopanoids elute after their unmethylated equivalents. b Analysis of Rhodopseudomonas palustris DSM127 as a control. This PNS bacterium produces 2-methylhopanoids (Rashby et al. 2007), which elute before their unmethylated equivalents. I.S., internal standard
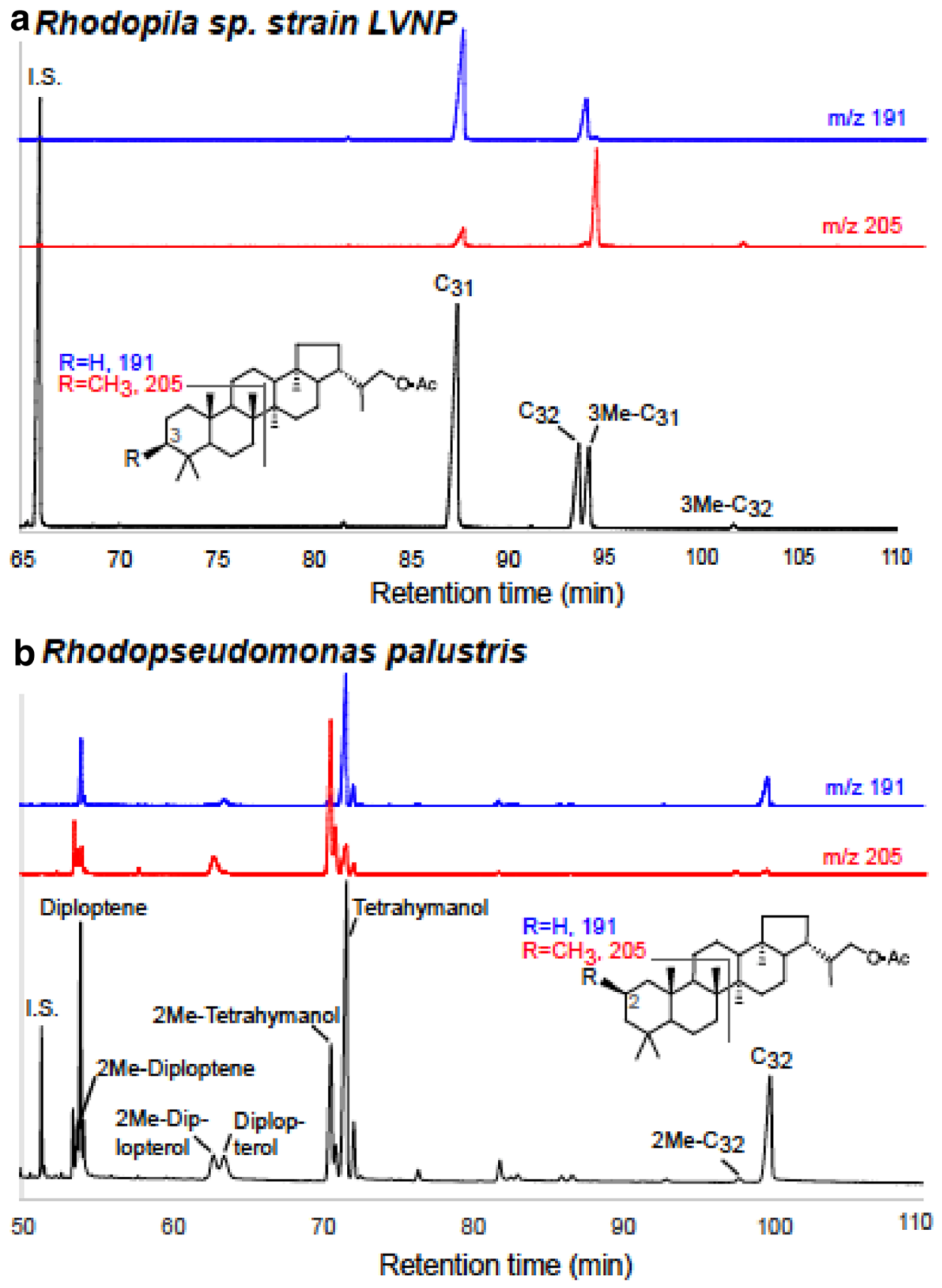

palustris did, however, contain 2-methylhopanoids as was previously reported (Rashby et al. 2007). Moreover, LC-MS analyses of cells of strain LVNP showed that it produced not only 3-methylhopanoids, but a suite of structurally related hopanoids as well. Although not quantified, LC-MS identified several extended hopanoids, including bacteriohopanetetrols and bacteriohopanetetrol cyclitol ethers (Table 2).

\section{Genomic evidence for 3-methylhopanoid production in Rhodopila species}

Genomic analyses in the Joint Genome Institute's IMG database confirmed that both Rhodopila sp. LVNP and Rpi. globiformis 7950 YNP (DSM161 ${ }^{\mathrm{T}}$ ) (Imhoff et al. 2018) were genetically equipped to produce 3-methylhopanoids (Table 3 ). Both strains were similar on the basis of their morphology, physiology, and pigments and are also close phylogenetic relatives. The C-3 hopanoid methylase $\mathrm{HpnR}$ is encoded in both genomes, and a phylogenetic tree 
Table 3 Locus tags of hopanoid biosynthesis gene homologues in our analyzed cultures of purple nonsulfur bacteria

\begin{tabular}{|c|c|c|c|c|c|}
\hline & Gene function & $\begin{array}{l}\text { Rhodopseudomonas } \\
\text { palustris ATCC } 17001 \\
\text { (JGI Genome ID } \\
2516653006 \text { ) }\end{array}$ & $\begin{array}{l}\text { Rhodoblastus aci- } \\
\text { dophilus DSM } 137 \\
\text { (JGI Genome ID } \\
2724679731 \text { ) }\end{array}$ & $\begin{array}{l}\text { Rhodopila globiformis } \\
\text { DSM } 161 \text { (JGI genome } \\
\text { ID 2831737867) }\end{array}$ & $\begin{array}{l}\text { Rhodopila sp. LVNP (JGI } \\
\text { genome ID 2684622831) }\end{array}$ \\
\hline $\begin{array}{l}\text { Total } \\
\text { genome } \\
\text { size }(M b)\end{array}$ & - & 5.2 & 4.7 & 7.2 & 8.1 \\
\hline$h p n R$ & $\begin{array}{l}\text { Methylates at C-3 posi- } \\
\text { tion }\end{array}$ & - & - & Ga0347445_1940 & Ga0132156_116223 \\
\hline shc & $\begin{array}{l}\text { Cyclizes squalene into } \\
\text { diploptene }\end{array}$ & RPATCC17001_01169 & Ga0170454_103148 & Ga0347445_5024 & Ga0132156_117315 \\
\hline hpnC & $\begin{array}{l}\text { Synthesizes the C30 } \\
\text { squalene substrate } \\
\text { from two isoprenoid } \\
\text { precursor farnesyl } \\
\text { pyrophosphate }(\mathrm{C} 15) \\
\text { molecules }\end{array}$ & RPATCC17001_01500 & Ga0170454_10337 & Ga0347445_3393 & Ga0132156_112831 \\
\hline hpnD & $\begin{array}{l}\text { Synthesizes the C30 } \\
\text { squalene substrate } \\
\text { from two isoprenoid } \\
\text { precursor farnesyl } \\
\text { pyrophosphate (C15) } \\
\text { molecules }\end{array}$ & RPATCC17001_01501 & Ga0170454_10338 & Ga0347445_3392 & Ga0132156_112832 \\
\hline hpnE & $\begin{array}{l}\text { Synthesizes the C30 } \\
\text { squalene substrate } \\
\text { from two isoprenoid } \\
\text { precursor farnesyl } \\
\text { pyrophosphate }(\mathrm{C} 15) \\
\text { molecules }\end{array}$ & RPATCC17001_01170 & Ga0170454_10339 & Ga0347445_5025 & Ga0132156_117314 \\
\hline hpnH & $\begin{array}{l}\text { First step in side chain } \\
\text { development by addi- } \\
\text { tion of an adenosyl } \\
\text { group to diploptene }\end{array}$ & RPATCC17001_01164 & Ga0170454_10877 & Ga0347445_577 & Ga0132156_114302 \\
\hline hpnG & $\begin{array}{l}\text { Cleaves an adenine from } \\
\text { the tail end of adeno- } \\
\text { sylhopane for side } \\
\text { chain modification }\end{array}$ & RPATCC17001_01168 & Ga0170454_10876 & Ga0347445_5023 & Ga0132156_117316 \\
\hline hpnI & $\begin{array}{l}\text { Glycosyltransferase that } \\
\text { helps generate the } \\
\text { extended hopanoid } \\
\text { glucosaminyl BHT }\end{array}$ & - & Ga0170454_1027 & Ga0347445_582 & Ga0347445_582 \\
\hline hpnJ & $\begin{array}{l}\text { Catalyzes a ring con- } \\
\text { traction to produce a } \\
\text { BHT cyclitol ether }\end{array}$ & - & Ga0170454_101616 & Ga0347445_583 & Ga0132156_114296 \\
\hline hpnK & $\begin{array}{l}\text { Deacetylates the BHT } \\
\text { acetylglucosamine } \\
\text { formed by HpnI to } \\
\text { generate the extended } \\
\text { hopanoid glucosami- } \\
\text { nyl BHT }\end{array}$ & - & - & Ga0347445_584 & Ga0132156_114295 \\
\hline hpnO & Generates amino BHT & RPATCC17001_01161 & Ga0170454_108103 & Ga0347445_6048 & Ga0132156_112646 \\
\hline hpnP & $\begin{array}{l}\text { Methylates at C-2 posi- } \\
\text { tion }\end{array}$ & RPATCC17001_04569 & - & - & - \\
\hline
\end{tabular}

- indicates gene absent

constructed from HpnR sequences (Fig. 4) mirrored the $16 \mathrm{~S}$ rRNA gene tree (Fig. 2). Specifically, HpnR from the Rhodopila species was related to HpnR from species of
Acetobacteraceae and distinct from that produced by methanotrophic Methylococcaceae (Fig. 4); the latter are wellknown producers of 3-methylhopanoids but are only distant 
Fig. 4 Protein tree of HpnR, the C-3 methylase that methylates hopanoids to form 3-methylhopanoids. Both Rhodopila strain LVNP and Rhodopila globiformis strain $7950 \mathrm{YNP}$ $\left(\mathrm{DSM} 161^{\mathrm{T}}\right)$ genomes encode HpnR (Table 3), and the amino acid sequences of this protein cluster with those from their close phylogenetic relatives, the acetic acid bacteria. C-2 hopanoid methylase (HpnP) from Rhodopseudomonas palustris was used as the outgroup in the tree. Numbers at the nodes are bootstrap percentages based on 1000 replications. Yellow highlighted taxa denote organisms that have confirmed 3-methylhopanoids in lipids obtained from cultured cells

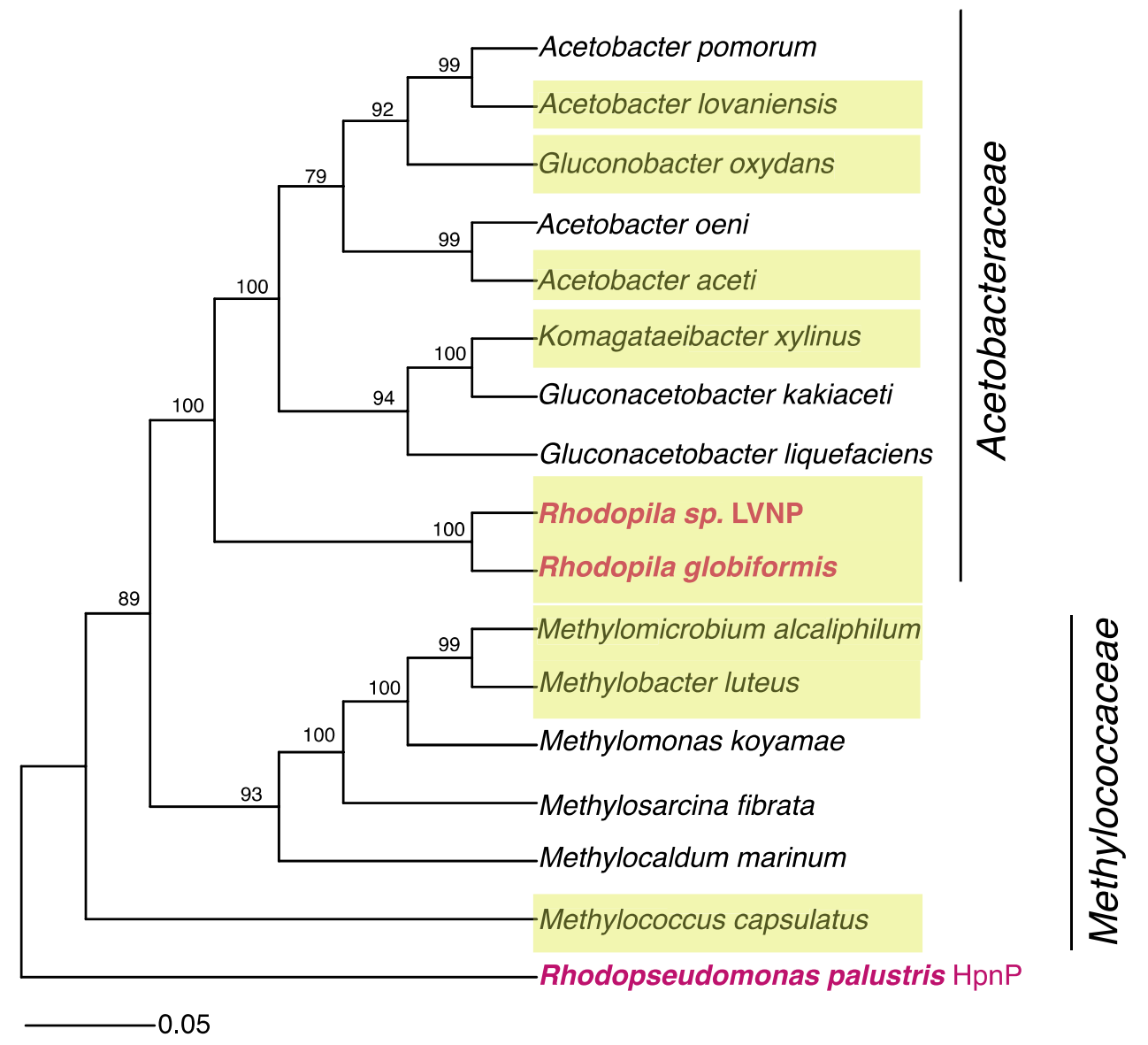

relatives of Acetobacteraceae (Fig. 2). Genes encoding several other hopanoid biosynthesis enzymes (Belin et al. 2018) were identified in the genomes of both Rhodopila strains (Table 3) consistent with the production of several related hopanoids identified from cells of Rhodopila strain LVNP (Table 2). The gene for tetrahymanol synthase (tsh) was not detected in the Rpi. globiformis strains (Query Locus Name MEALZ_1626), as evidenced by the lack of detection of tetrahymanol in lipid extracts (Table 1).

\section{Discussion}

Our results are the first to show the production of 3-methylhopanoids in bacteria grown anaerobically, thus refuting the contention that these lipids are only produced by obligately aerobic bacteria. It is thus possible, and perhaps even likely, that these lipids are produced by various anaerobes, but only in species of Bacteria, since to date no species of Archaea have been shown to contain hopanoids (Sahm et al. 1993).

The physiological link between acetic-acid bacteria and Rhodopila does not revolve around energy metabolism but instead the ability of both organisms to thrive in strongly acidic habitats. Whether such a lifestyle requires these unusual lipids is unknown, but the fact that 3-methylhopanoids are produced by many neutrophilic methanotrophic bacteria and have not been reported from some other potentially acidophilic bacteria, such as Thiobacillus (Rohmer et al. 1979), leaves this question unanswered. Nevertheless, 3-methylhopanoids obviously play some role in the physiology of Rhodopila species, and the genetic links between this phototroph and acidophilic bacteria (Fig. 2) and the fact that the analogous 2-methylhopanoids are membrane integrated (Doughty et al. 2009), suggest that 3-methylhopanoids may help maintain membrane function in their acidic habitats. Indeed, a function for hopanoids in maintaining membrane integrity and surviving general environmental stressors has been shown in the cyanobacterium Nostoc punctiforme (Ricci et al. 2017). In addition, it has been shown that extended hopanoids aid the chemotrophic bacterium Bradyrhizobium diazoefficiens in withstanding hypoxic/ low $\mathrm{O}_{2}$ growth conditions and various other physiological stressors (Kulkarni et al. 2015). Hence, if there exists a widespread link between 3-methylhopanoids and microbes that inhabit extreme environments, it is possible that in addition to the example we have shown with acidophilic Rhodopila species, these hopanoids are produced by anoxygenic phototrophs that thrive in hypersaline, hyperalkaline, and 
permanently hot or cold environments as well; all of these habitats contain a diversity of purple bacteria (Madigan and Jung 2009; Jahnke et al. 2014).

Production of 3-methylhopanoids by Rhodopila highlights the potential importance of anoxygenic phototrophs in the geological rock record and has at least two major geological implications. First, the fact that anaerobically grown Rhodopila species can produce 3-methylhopanoids-lipids heretofore observed only in bacteria whose metabolism requires $\mathrm{O}_{2}$-indicates that the presence of 3-methylhopanes (the degradation product of 3-methylhopanoids) in ancient rocks can no longer be used as prima facie evidence that oxic conditions existed at the time of deposition. Consequently, linking 3-methylhopanes to $\mathrm{O}_{2}$-dependent bacterial metabolisms, such as aerobic methanotrophy (Brocks et al. 2005; Farrimond et al. 2004; Waldbauer et al. 2009), should be done cautiously and only with corroborating evidence.

Second, the relatively high abundance of 3-methylhopanes in mid-Proterozoic marine (Brocks et al. 2005) and Phanerozoic saline lacustrine sediments (French et al. 2020) has been used to infer low sulfate conditions in these aquatic environments, a link that is now called into question. This is because in low sulfate settings, methanogenic Archaea typically outcompete sulfate-reducing bacteria for substrates (Hoehler et al. 1998). Thus, in ancient sediments containing 3-methylhopanes, it has been assumed that the increased levels of methane fed the 3-methylhopanoid-containing methanotrophs. However, because our results show that 3-methylhopanes can no longer be unambiguously connected to methanotrophic (or any other obligately aerobic) bacteria, concluding that a given sedimentary rock containing 3-methylhopanes must have formed in low sulfate conditions (Brocks et al. 2005; French et al. 2020) may be erroneous.

Acknowledgements Microbial mat samples from Lassen Volcanic National Park were collected under U.S. National Park Service permit LAVO-2014-SCI-0003. We thank Roger Summons and the Welander Lab for helpful discussions, and Xiaolei Liu and Thomas Evans for LC-MS analyses.

Author contributions MNP, MHM, and MLK generated the data. MTM drafted the manuscript and all authors contributed to editing the manuscript.

Funding This study was supported by NASA Exobiology Grant NNX15AM17G to MNP, LLJ, MTM, and PVW, and a NASA Internal Scientist Funding Model (ISFM) Grant to MNP and LLJ. The Rhodopila globiformis strain LVNP genome was sequenced during the 2016 Woods Hole (Massachusetts, USA) Marine Biological Laboratory Microbial Diversity Summer Course.

Availability of data and materials Data from Rhodopila strain LVNP are available from MNP upon request. Accession Numbers for $16 \mathrm{~S}$ rRNA gene sequences obtained from Genbank and used in Fig. 2: Gluconobacter oxydans DSM7145 (X73820), Acetobacter aceti DSM 3508 (NR_026121), Kozakia baliensis DSM 14400 (AB056321), Gluconoacetobacter liquefaciens DSM 5603 (X75617), Komagataeibacter xylinus DSM 6153 (NR_036787), Acidisphaera rubrifaciens HS-AP3 (NR_037119), Rhodopila sp. LVNP (MZ461013), Rhodopila globiformis DSM 161 (NR_037120), Rhodobacter capsulatus DSM 1710 (NR_043407), Rhodobaca bogoriensis DSM 18756 (AF248638), Rhodoblastus acidophilus DSM 137 (NR_104756), Rhodopseudomonas palustris ATCC 17001 (NR_115542), Rhodospirillum rubrum DSM 467 (D30778), Phaeospirillum molischianum DSM 120 (FR733695), Rhodoferax antarcticus DSM 24876 (GU233447), Rhodocyclus purpureus DSM 168 (M34132), Methylobacter luteus (X72772), Thermochromatium tepidum DSM 3771 (MN699348), Methylococcus capsulatus ATCC 19069 (NR_042183). IMG Genome IDs for sequences obtained from JGI IMG Database and used in Fig. 3: Rhodopila sp. LVNP (2684622831), Rhodopseudomonas palustris 7850 DSM 127 (2516653012). IMG Genome IDs for HpnR sequences obtained from JGI IMG Database and used in Fig. 4: Acetobacter pomorum (2828617574), Acetobacter lovaniensis (2861688124), Gluconobacter oxydans (2784746773), Acetobacter oeni (2829864053), Acetobacter aceti (2784746776), Komagataeibacter xylinus (2841172115), Gluconacetobacter kakiaceti (2828350867), Gluconacetobacter liquefaciens (2756170231), Rhodopila sp. LVNP (2684622831), Rhodopila globiformis (2831737867), Methylomicrobium alcaliphilum (2540341096), Methylobacter luteus (2517287033), Methylomonas koyamae (2728369704), Methylosarcina fibrata (2517487019), Methylocaldum marinum (2832923104), Methylococcus capsulatus (637000166), Rhodopseudomonas palustris (2516653012).

Code availability Not applicable.

\section{Declarations}

Conflict of interest The authors declare they have no financial or other conflicts of interests.

Open Access This article is licensed under a Creative Commons Attribution 4.0 International License, which permits use, sharing, adaptation, distribution and reproduction in any medium or format, as long as you give appropriate credit to the original author(s) and the source, provide a link to the Creative Commons licence, and indicate if changes were made. The images or other third party material in this article are included in the article's Creative Commons licence, unless indicated otherwise in a credit line to the material. If material is not included in the article's Creative Commons licence and your intended use is not permitted by statutory regulation or exceeds the permitted use, you will need to obtain permission directly from the copyright holder. To view a copy of this licence, visit http://creativecommons.org/licenses/by/4.0/.

\section{References}

Altschul SF, Gish W, Miller W et al (1990) Basic local alignment search tool. J Mol Biol 215:403-410. https://doi.org/10.1016/ S0022-2836(05)80360-2

Altschul SF, Madden TL, Schäffer AA et al (1997) Gapped BLAST and PSI-BLAST: a new generation of protein database search programs. Nucleic Acids Res 25:3389-3402. https://doi.org/10. 1093/nar/25.17.3389

Belin BJ, Busset N, Giraud E et al (2018) Hopanoid lipids: from membranes to plant-bacteria interactions. Nat Rev Microbiol 16:304. https://doi.org/10.1038/nrmicro.2017.173

Brocks JJ, Schaeffer P (2008) Okenane, a biomarker for purple sulfur bacteria (Chromatiaceae), and other new carotenoid derivatives 
from the 1640Ma Barney Creek Formation. Geochim Cosmochim Acta 72:1396-1414. https://doi.org/10.1016/j.gca.2007.12.006

Brocks JJ, Love GD, Summons RE et al (2005) Biomarker evidence for green and purple sulphur bacteria in a stratified Palaeoproterozoic sea. Nature 437:866-870. https://doi.org/10.1038/nature04068

Chen I-MA, Chu K, Palaniappan K et al (2019) IMG/M vol 5.0: an integrated data management and comparative analysis system for microbial genomes and microbiomes. Nucleic Acids Res 47:D666-D677. https://doi.org/10.1093/nar/gky901

Doughty DM, Hunter RC, Summons RE, Newman DK (2009) 2-Methylhopanoids are maximally produced in akinetes of Nostoc punctiforme: geobiological implications. Geobiology 7:524-532. https:// doi.org/10.1111/j.1472-4669.2009.00217.x

Edgar RC (2004) MUSCLE: multiple sequence alignment with high accuracy and high throughput. Nucleic Acids Res 32:1792-1797. https://doi.org/10.1093/nar/gkh340

Farrimond P, Talbot HM, Watson DF et al (2004) Methylhopanoids: molecular indicators of ancient bacteria and a petroleum correlation tool. Geochim Cosmochim Acta 68:3873-3882. https://doi. org/10.1016/j.gca.2004.04.011

French KL, Birdwell JE, Vanden Berg MD (2020) Biomarker similarities between the saline lacustrine Eocene Green River and the Paleoproterozoic Barney Creek Formations. Geochim Cosmochim Acta 274:228-245. https://doi.org/10.1016/j.gca.2020.01.053

Guindon S, Dufayard J-F, Lefort V et al (2010) New algorithms and methods to estimate maximum-likelihood phylogenies: assessing the performance of PhyML 3.0. Syst Biol 59:307-321. https://doi.org/10.1093/sysbio/syq010

Harwood CS, Gibson J (1988) Anaerobic and aerobic metabolism of diverse aromatic compounds by the photosynthetic bacterium Rhodopseudomonas palustris. Appl Environ Microbiol 54:712-717. https://doi.org/10.1128/aem.54.3.712-717.1988

Hoehler TM, Alperin MJ, Albert DB, Martens CS (1998) Thermodynamic control on hydrogen concentrations in anoxic sediments. Geochim Cosmochim Acta 62:1745-1756. https://doi.org/10. 1016/S0016-7037(98)00106-9

Hohmann-Marriott MF, Blankenship RE (2011) Evolution of photosynthesis. Ann Rev Plant Biol 62:515-548. https://doi.org/10. 1146/annurev-arplant-042110-103811

Huntemann M, Ivanova NN, Mavromatis K et al (2015) The standard operating procedure of the DOE-JGI Microbial Genome Annotation Pipeline (MGAP vol 4). Stand Genomic Sci 10:86. https://doi.org/10.1186/s40793-015-0077-y

Imhoff JF, Madigan MT (2021) Rhodopila. Bergey's manual of systematics of archaea and bacteria. Wiley. https://doi.org/10.1002/ 9781118960608.gbm00886.pub2

Imhoff JF, Rahn T, Künzel S, Neulinger SC (2018) New insights into the metabolic potential of the phototrophic purple bacterium Rhodopila globiformis DSM $161^{\mathrm{T}}$ from its draft genome sequence and evidence for a vanadium-dependent nitrogenase. Arch Microbiol 200:847-857. https://doi.org/10.1007/ s00203-018-1489-z

Jahnke LL, Stan-Lotter H, Kato K, Hochstein LI (1992) Presence of methyl sterol and bacteriohopanepolyol in an outer-membrane preparation from Methylococcus capsulatus (Bath). J Gen Microbiol 138:1759-1766. https://doi.org/10.1099/00221 287-138-8-1759

Jahnke LL, Eder W, Huber R et al (2001) Signature lipids and stable carbon isotope analyses of octopus spring hyperthermophilic communities compared with those of aquificales representatives. Appl Environ Microbiol 67:5179-5189. https://doi.org/ 10.1128/AEM.67.11.5179-5189.2001

Jahnke LL, Turk-Kubo KA, Parenteau MN et al (2014) Molecular and lipid biomarker analysis of a gypsum-hosted endoevaporitic microbial community. Geobiology 12:62-82. https://doi.org/10. 1111/gbi.12068
Kersters K, Lisdiyanti P, Komagata K, Swings J (2006) The Family Acetobacteraceae: The Genera Acetobacter, Acidomonas, Asaia, Gluconacetobacter, Gluconobacter, and Kozakia. The Prokaryotes. Springer, New York, pp 163-200. https://doi.org/ 10.1007/0-387-30745-1_9

Kulkarni G, Busset N, Molinaro A et al (2015) Specific hopanoid classes differentially affect free-living and symbiotic states of Bradyrhizobium diazoefficiens. Mbio. https://doi.org/10.1128/ mBio.01251-15

Lefort V, Longueville J-E, Gascuel O (2017) SMS: smart model selection in PhyML. Mol Biol Evol 34:2422-2424. https://doi. org/10.1093/molbev/msx149

Letunic I, Bork P (2019) Interactive Tree Of Life (iTOL) v4: recent updates and new developments. Nuc Acids Res 47:W256W259. https://doi.org/10.1093/nar/gkz239

Madigan MT, Jung DO (2009) An overview of purple bacteria: systematics, physiology, and habitats. The purple phototrophic bacteria. Springer, Netherlands, pp 1-15. https://doi.org/10.1007/ 978-1-4020-8815-5_1

Matys ED, Mackey T, Grettenberger C et al (2019) Bacteriohopanepolyols across environmental gradients in Lake Vanda, Antarctica. Geobiology 17:308-319. https://doi.org/10.1111/gbi.12335

Pfennig N (1974) Rhodopseudomonas globiformis, sp. n., a new species of the Rhodospirillaceae. Arch Microbiol 100:197-206. https:// doi.org/10.1007/BF00446317

Rashby SE, Sessions AL, Summons RE, Newman DK (2007) Biosynthesis of 2-methylbacteriohopanepolyols by an anoxygenic phototroph. Proc Natl Acad Sci (USA) 104:15099-15104. https://doi. org/10.1073/pnas.0704912104

Ricci JN, Michel AJ, Newman DK (2015) Phylogenetic analysis of HpnP reveals the origin of 2-methylhopanoid production in Alphaproteobacteria. Geobiology 13:267-277. https://doi.org/10. 1111/gbi.12129

Ricci JN, Morton R, Kulkarni G et al (2017) Hopanoids play a role in stress tolerance and nutrient storage in the cyanobacterium Nostoc punctiforme. Geobiology 15:173-183. https://doi.org/10. 1111/gbi.12204

Rohmer M, Bouvier P, Ourisson G (1979) Molecular evolution of biomembranes: structural equivalents and phylogenetic precursors of sterols. Proc Natl Acad Sci (USA) 76:847-851. https:// doi.org/10.1073/pnas.76.2.847

Rohmer M, Bouvier-Nave P, Ourisson G (1984) Distribution of hopanoid triterpenes in prokaryotes. Microbiology 130:1137-1150. https://doi.org/10.1099/00221287-130-5-1137

Sahm H, Rohmer M, Bringer-Meyer S et al (1993) Biochemistry and physiology of hopanoids in bacteria. In: Advances in microbial physiology. Academic Press, London, pp 247-273. https://doi.org/ 10.1016/S0065-2911(08)60100-9

Schmidt K, Liaaen-Jensen S (1973) Bacterial carotenoids. XLII. New keto-carotenoids from Rhodopseudomonas globiformis (Rhodospirillaceae). Acta Chem Scand 27:3040-3052. https://doi.org/ 10.3891/acta.chem.scand.27-3040

Sessions AL, Zhang L, Welander PV et al (2013) Identification and quantification of polyfunctionalized hopanoids by high temperature gas chromatography-mass spectrometry. Org Geochem 56:120-130. https://doi.org/10.1016/j.orggeochem.2012.12.009

Sievers F, Wilm A, Dineen D et al (2011) Fast, scalable generation of high-quality protein multiple sequence alignments using Clustal Omega. Mol Syst Biol 7:539. https://doi.org/10.1038/msb.2011.75

Summons RE, Jahnke LL (1990) Identification of the methylhopanes in sediments and petroleum. Geochim Cosmochim Acta 54:247-251. https://doi.org/10.1016/0016-7037(90)90212-4

Summons RE, Jahnke LL, Hope JM, Logan GA (1999) 2-Methylhopanoids as biomarkers for cyanobacterial oxygenic photosynthesis. Nature 400:554-557. https://doi.org/10.1038/23005 
Talbot HM, Squier AH, Keely BJ, Farrimond P (2003) Atmospheric pressure chemical ionisation reversed-phase liquid chromatography/ion trap mass spectrometry of intact bacteriohopanepolyols. Rapid Commun Mass Spectrom 17:728-737. https://doi.org/10. 1002/rcm.974

Talbot HM, Rohmer M, Farrimond P (2007) Rapid structural elucidation of composite bacterial hopanoids by atmospheric pressure chemical ionisation liquid chromatography/ion trap mass spectrometry. Rapid Commun Mass Spectrom 21:880-892. https:// doi.org/10.1002/rcm.2911

Turner S, Pryer KM, Miao VPW, Palmer JD (1999) Investigating deep phylogenetic relationships among cyanobacteria and plastids by small subunit rRNA sequence analysis. J Eukaryot Microbiol 46:327-338. https://doi.org/10.1111/j.1550-7408.1999.tb04612.x

Waldbauer JR, Sherman LS, Sumner DY, Summons RE (2009) Late Archean molecular fossils from the Transvaal Supergroup record the antiquity of microbial diversity and aerobiosis. Precambr Res 169:28-47. https://doi.org/10.1016/j.precamres.2008.10.011

Welander PV, Summons RE (2012) Discovery, taxonomic distribution, and phenotypic characterization of a gene required for 3-methylhopanoid production. Proc Natl Acad Sci (USA) 109:12905-12910. https://doi.org/10.1073/pnas.1208255109

Yildiz FH, Gest H, Bauer CE (1991) Attenuated effect of oxygen on photopigment synthesis in Rhodospirillum centenum. J Bacteriol 173:5502-5506. https://doi.org/10.1128/jb.173.17.5502-5506. 1991

Zhu C, Talbot HM, Wagner T et al (2011) Distribution of hopanoids along a land to sea transect: Implications for microbial ecology and the use of hopanoids in environmental studies. Limnol Oceanogr 56:1850-1865. https://doi.org/10.4319/lo.2011.56.5.1850

Zundel M, Rohmer M (1985) Prokaryotic triterpenoids. Eur J Biochem 150:23-27. https://doi.org/10.1111/j.1432-1033.1985.tb08980.x

Publisher's Note Springer Nature remains neutral with regard to jurisdictional claims in published maps and institutional affiliations. 